\title{
Awareness of the role of cardiovascular risk factors and their prevention - comparison between rural-urban and urban adolescents
}

\author{
Dawid Ostrówka ${ }^{1,2} \odot$, Tadeusz Dereziński ${ }^{\circledR}$, Maria Nowak ${ }^{4}$, \\ Anna Komand ${ }^{1}$, Marta Jancewicz ${ }^{1}$, Anna Szyndler ${ }^{1} \odot$, Jacek Wolf ${ }^{1} \odot$, \\ Krzysztof Narkiewicz ${ }^{1}$ 우
}

\begin{abstract}
${ }^{1}$ Department of Hypertension and Diabetology, Faculty of Medicine, Medical University of Gdańsk, Gdańsk, Poland; Center of Translational Medicine, Medical University of Gdańsk, Gdańsk, Poland

${ }^{2}$ Department of Pediatrics, Heamatology and Oncology, Faculty of Medicine, Medical University of Gdańsk, Gdańsk, Poland ${ }^{3}$ NZOZ Esculap, Gniewkowo, Poland

${ }^{4}$ First Department of Cardiology, Faculty of Medicine, Medical University of Gdańsk, Gdańsk, Poland
\end{abstract}

\begin{abstract}
Background: Unhealthy habits (poor diet, smoking and hazardous alcohol drinking) often originate from early-life. We assessed the knowledge on selected cardiovascular and cancer risk factors, healthy habits and its implementation among adolescents and the correlation with their place of residence. Materials and methods: A survey-based study (38-item inventory) was conducted among adolescents from urban and rural-urban areas recruited in two Tricity high-schools and one junior high school from Gniewkowo, respectively. Results: A total of 410 students (59\% girls) from Tricity and 287 ( $51 \%$ girls) from Gniewkowo completed the inventory. The mean age was 15.3 years. Students from Gniewkowo spend weekly $8.9 \pm 6.2$ hours on structured physical activity, which contrasts with $5.5 \pm 4.5$ hrs in Tricity $(P<0.001)$. Gniewkowo residents restrained from alcohol consumption in $38.7 \%$ vs. $31.1 \%$ in Tricity $(P=0.04)$; were active smokers at $9.4 \%$ vs. $4.2 \%(P=0.007)$; regular fruits and vegetables consumption was low in both Gniewkowo and Tricity $11.8 \%$ vs. $8.6 \%(P=0.19)$; respectively. The awareness of the risk factors of non-communicable diseases was more common amongst Tricity adolescents. This was consistently coupled with the knowledge on preventive methods. Conclusions: The level of knowledge on common non-communicable disease risk factors is higher among teenagers from urban areas, however this does not necessarily translate to more frequent introduction of healthy lifestyle.
\end{abstract}

Keywords: CVD risk factors $\cdot$ adolescents $\cdot$ smoking $\cdot$ physical activity

\section{Citation}

Ostrówka D, Dereziński T, Nowak M, Komand A, Jancewicz M, Szyndler A, Wolf J, Narkiewicz K. Awareness of the role of cardiovascular risk factors and their prevention - comparison between rural-urban and urban adolescents. Eur J TransI Clin Med. 2019;2(2):27-37.

DOI: $10.31373 /$ ejtcm/116002

Corresponding author:

Anna Szyndler, Department of Hypertension and Diabetology, Faculty of Medicine, Medical University of Gdańsk, Gdańsk, Poland:

Center of Translational Medicine, Medical University of Gdańsk, Gdańsk, Poland

e-mail: anna.szyndler@gumed.edu.pl

No external funds.

Available online: www.eitcm.gumed.edu.pl

This is Open Access article distributed under the terms of the Creative Commons Attribution-ShareAlike 4.0 International. 


\section{Introduction}

Most of the chronic non-communicable diseases and unhealthy habits of the middle- and older-age, such as obesity, hypertension, smoking, excessive salt intake and alcohol consumption originate from childhood and adolescence. Of more, there is a compelling body of evidence showing that the classical environmental risk factors (primarily recognized in adulthood) negatively determine cardiovascular (CV) risk in early life-time. This generally holds true to insufficient level of education about healthy habits along with its implementation into daily life (e.g. physical activity, diet or body weight control). Evidently, body weight excess constitutes the most important single contributing factor to childhood hypertension [1-2]. This is of particular importance as the prevalence of obesity has considerably increased among children during the recent decades [3-4]. Today it is clear that the obesity epidemic will translate to shorter life span of todays' generation as compared to their parents' [5-6].

Additionally, novel risk factors emerged recently such as the growing popularity of e-cigarettes among adolescents. This may have a detrimental impact on recently recorded favorable trends in smoking cessation records. Smoking in the childhood is a recognized and very potent risk factor for continued smoking in adulthood [7-8].

Given that cardiovascular diseases are a leading cause of premature death, effective preventive methods should be implemented as early as possible. Adolescents should be aware of different ways of reducing CV risk which need to be implemented on every day basis.

Therefore, we aimed to assess the awareness of CV risk factors, the knowledge about $\mathrm{CV}$ preventive measures, and the true lifestyle habits in two groups of adolescents recruited from urban and rural-urban areas of Poland (i.e. the Tricity and town of Gniewkowo).

\section{Materials and methods}

In the years 2016-2017 groups of junior-high (from the rural-urban area of Gniewkowo, 8 thousand inhabitants) and high school students (Tricity agglomeration, $\sim 1$ million inhabitants) were enrolled into the study. All students volunteered to participate in the study. Those who did not consent or their parents/legal guardians did not provide an informed consent were not included in the survey (Attachment 1). During their school hours, the participants anonymously answered the 38-item questionnaire (questions adopted after Ostrówka D. et al.) [9]. The questionnaire composed of two main domains related to the awareness of risk factors (1) and the self-reported lifestyle habits such as physical activity, dietary approach, and substance use (2). The section regarding attitudes and practices included multiple-choice as well as open questions. Basic anthropometric and medical family history data was also collected i.e. weight, height, as well as their parents' CVD history. The anthropometric data was matched with Polish adolescent-specific percentile charts. The collected data was tabulated in MS Excel and analyzed with standard statistical package (Statistica 10, Statsoft, Poland). Chi-square test and student's t-test were used to assess the statistical significance for the comparison between two groups. P-value $<0.05$ was considered statistically significant.

\section{Results}

A total of 697 students were enrolled into the study; 410 from urban area schools $(243,59.3 \%$ were girls) and in 287 from rural-urban area (146, 50.9\% were girls). The mean age of the surveyed students was 15.3 years ( $14.3 \pm 0.9$ years in Gniewkowo, $16.4 \pm$ 0.5 years in Gdańsk; $P<0.001)$. Based on self-reported weight and height, the students' BMI were assessed and matched with Polish adolescent-specific percentile charts [10] (Figure 2).

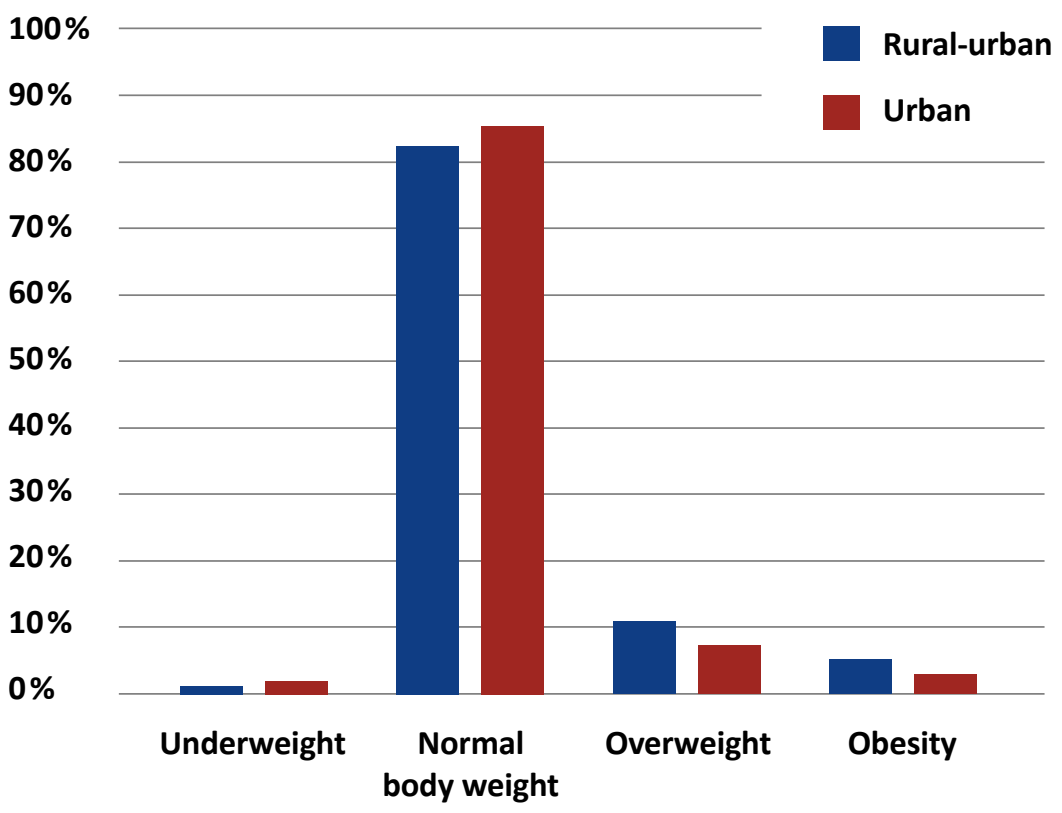

Figure 2. Comparison of BMI among our rural-urban and urban respondents 


\section{Physical activity}

Awareness of the positive role of regular physical activity in the prevention of cardiovascular disease was significantly lower in the rural-urban population. The results of our study show that in both groups approximately 7 out of 10 students participate in out-of-school physical activities in urban and rural-urban areas; this was comparable in both studied groups. Additionally, no differences between the rural-urban and urban area students were noted with respect to number of sport activities (Table 1). Rural-urban adolescents, however, claim to spend more time on physical activity, on both daily $(1.99 \pm 1.24 \mathrm{~h}$ vs. $1.39 \pm$ $1.00 \mathrm{~h}$ ) and weekly basis ( $8.86 \pm 6.17 \mathrm{~h}$ vs $5.5 \mathrm{~h} \pm 4.5 \mathrm{~h}$ ) as compared to their peers from the urban area. At the same time the percentage of students, who declared spending 2 or more hours and 4 or more hours in front of TV set or computer was comparable between groups.

\section{Smoking and psychoactive substances}

Approximately, one-third of the rural-urban area students have already started tobacco smoking in the- ir early years whereas in the urban agglomeration this phenomenon was less common and noted among $20 \%$ of our respondents $(P=0.002)$. The age of rural-urban students, who smoked their first-ever cigarette was significantly lower than among the urban students $(12.0 \pm 2.8$ yrs vs. $14.6 \pm 1.4 \mathrm{yrs} ; \mathrm{P}<0.001)$. Twice as many adolescents in the rural-urban area declared active smoking as in the urban area $(9.4 \%$ vs. $4.2 \%$; $P<0.01)$. Furthermore, the rural-urban students who used tobacco regularly tended to smoke over 3 times more cigarettes per day than their smoking urban peers (Table 2).

Tobacco usage was also more prevalent among the parents of the rural-urban adolescents: $56.6 \%$ of students have at least one smoking parent, in comparison to urban parents where only $23.7 \%$ of them smoke on daily basis. Therefore, the percentage of students exposed to passive smoking in rural-urban area is twice as high as in the urban agglomeration (Table 2).

Urban students identified tobacco usage as a possible cause of cancer and lung diseases more frequently than their rural-urban peers. Only two thirds of students in both groups associated smoking cigarettes with CVD, and less than half of the students, irrespective of their place of residence, identified smoking as a risk factor of stroke (Table 2 ).

Table 1. Attitude towards sport and sedentary lifestyle among our rural-ubran and urban respondents

\begin{tabular}{|c|c|c|c|}
\hline & Rural-urban & Urban & P-value \\
\hline $\begin{array}{l}\text { Percentage of students involved in } \\
\text { out of school physical activities } \geq 1 \text { /week }\end{array}$ & $70.0 \%$ & $73.4 \%$ & 0.34 \\
\hline Average time spent daily on physical activity $(h)$ & $1.99 \pm 1.24$ & $1.39 \pm 1.00$ & $<0.001$ \\
\hline Average time spent weekly on physical activity $(h)$ & $8.86 \pm 6.17$ & $5.5 \pm 4.5$ & $<0.001$ \\
\hline $\begin{array}{c}\text { Students participating } \\
\text { in } 3 \text { or more types of sport disciplines }\end{array}$ & $8.7 \%$ & $10.0 \%$ & 0.79 \\
\hline $\begin{array}{l}\text { Students using computer or TV set } \\
\text { for } 2 \text { or more hours per day }\end{array}$ & $48.6 \%$ & $47.2 \%$ & 0.76 \\
\hline $\begin{array}{l}\text { Students using computer or TV set } \\
\text { for } 4 \text { or more hours per day }\end{array}$ & $13.6 \%$ & $14.0 \%$ & 0.91 \\
\hline $\begin{array}{c}\text { Students who consider regular physical activity } \\
\text { as a CVD protective measure }\end{array}$ & $86.0 \%$ & $97.1 \%$ & $<0.001$ \\
\hline
\end{tabular}


Table 2. Awareness of the role of smoking and excessive alcohol consumption in the development of cardiovascular disease

\begin{tabular}{|c|c|c|c|}
\hline & Rural-urban & Urban & P-value \\
\hline \multicolumn{4}{|c|}{ Alcohol and recreational drugs related data } \\
\hline Students who never drank alcohol & $38.7 \%$ & $31.1 \%$ & 0.04 \\
\hline $\begin{array}{l}\text { Students who consider excessive alcohol } \\
\text { consumption to cause hypertension }\end{array}$ & $67.4 \%$ & $67.7 \%$ & 0.93 \\
\hline Students who tried drugs in the past & $13.4 \%$ & $13.2 \%$ & 1 \\
\hline Students who witnessed drugs use & $29.7 \%$ & $43.6 \%$ & $<0.001$ \\
\hline \multicolumn{4}{|c|}{ Smoking-related data } \\
\hline Students who tried smoking in the past & $31.0 \%$ & $21.1 \%$ & 0.002 \\
\hline Average age of smoking initiation [years] & $12.0 \pm 2.8$ & 14. $6 \pm 1.4$ & $<0.001$ \\
\hline Proportion of current smokers & $9.4 \%$ & $4.2 \%$ & 0.007 \\
\hline Average number of cigarettes smoked per day & 10.4 & 3.4 & $<0.001$ \\
\hline Current smokers' years of smoking [years] & 3.4 & 2.6 & 0.33 \\
\hline Current smokers with at least one parent smoking & $81.4 \%$ & $47.1 \%$ & 0.02 \\
\hline $\begin{array}{l}\text { Non-smoking students } \\
\text { who have at least one parent smoking }\end{array}$ & $53.7 \%$ & $22.6 \%$ & $<0.001$ \\
\hline $\begin{array}{l}\text { Students informed by health professionals } \\
\text { about negative effects of smoking }\end{array}$ & $34.7 \%$ & $43.3 \%$ & 0.03 \\
\hline
\end{tabular}

Students who consider smoking to cause

\begin{tabular}{|c|c|c|c|}
\hline cancer & $85.0 \%$ & $98.0 \%$ & $<0.001$ \\
\hline heart diseases & $79.1 \%$ & $82.4 \%$ & 0.28 \\
\hline stroke & $45.6 \%$ & $39.9 \%$ & 0.14 \\
\hline lung diseases & $91.9 \%$ & $98.5 \%$ & 0.001 \\
\hline hypertension & $64.7 \%$ & $64.8 \%$ & $<0.001$ \\
\hline $\begin{array}{c}\text { Students who consider reduction of smoking and } \\
\text { alcohol consumption to decrease risk of CVD }\end{array}$ & $73.9 \%$ & $91.2 \%$ & $<$ \\
\hline
\end{tabular}


A different trend was observed in terms of alcohol use in between the studied groups. Rural-urban students more often indicated that they have never drank alcohol in their life. Whereas the number of students who experimented with illicit psychoactive substances was comparable in both of the studied groups with up to $15 \%$ more rural-urban adolescents reporting eye-witnessed drug use.

\section{Dietary habits}

The number of students, who declare to eat 5 or more portions of fruits and vegetables per day, is low in both groups. Only around half of the studied popu- lations reports eating low-fat diet on a regular basis, and portion of adolescents, who eat fast food is almost 2 times higher in the urban area. Detailed comparisons are summarized in Table 3.

\section{Knowledge of CVD risk factors}

The awareness of CVD risk factors was lower in the rural-urban area group. The percentage of correct answers to all the questions in this domain was lower by $10-20 \%$ among those students. An exception is the question about regular fruit and vegetable consumption - the answers were almost the same in both groups $(P>0.05)$ (Table 4).

Table 3. Dietary habits of our rural-urban and urban respondents

\begin{tabular}{|c|c|c|} 
& Rural-urban & Urban \\
\hline $\begin{array}{c}\text { Students who eat } \geq 5 \text { portions } \\
\text { of fruit or vegetables/day }\end{array}$ & $11.8 \%$ & $8.6 \%$ \\
\hline Students who eat fast food $\geq 1 /$ week & $26.2 \%$ & $44.8 \%$ \\
\hline Students who declare to reduce fat in their diet & $59.5 \%$ & $55.5 \%$ \\
\hline Students who add salt to their meals & 0.30 & $35.1 \%$ \\
\hline
\end{tabular}

Table 4. The awareness of and applying CVD risk-reducing activities into daily life

\begin{tabular}{|c|c|c|c|c|c|}
\hline \multicolumn{3}{|c|}{$\begin{array}{l}\text { Students who } \\
\text { consider } \\
\text { the following } \\
\text { activities } \\
\text { to reduce } \\
\text { risk of CVD }\end{array}$} & \multicolumn{3}{|c|}{$\begin{array}{l}\text { Students who } \\
\text { regularly apply } \\
\text { the following } \\
\text { activity in } \\
\text { their daily life }\end{array}$} \\
\hline $\begin{array}{l}\text { Rural- } \\
\text {-urban }\end{array}$ & Urban & P-value & $\begin{array}{l}\text { Rural- } \\
\text {-urban }\end{array}$ & Urban & $\begin{array}{c}\text { P- } \\
\text {-value }\end{array}$ \\
\hline $73.9 \%$ & $93.9 \%$ & $<0.001$ & $77.1 \%$ & $81.1 \%$ & 0.21 \\
\hline $86.0 \%$ & $97.1 \%$ & $<0.001$ & $72.5 \%$ & $68.6 \%$ & 0.27 \\
\hline $73.9 \%$ & $91.2 \%$ & $<0.001$ & $84.6 \%$ & $91.1 \%$ & 0.01 \\
\hline $66.2 \%$ & $82.3 \%$ & $<0.001$ & $61.8 \%$ & $61.7 \%$ & 1 \\
\hline $80.5 \%$ & $83.1 \%$ & 0.42 & $80.4 \%$ & $87.3 \%$ & 0.02 \\
\hline $66.8 \%$ & $86.2 \%$ & $<0.001$ & $59.5 \%$ & $55.5 \%$ & 0.31 \\
\hline
\end{tabular}


Table 5. The percentage of students correctly identifying diseases that are a consequence of HT

\begin{tabular}{|c|c|c|}
\hline Urban & Rural-urban & P-value \\
Stroke & $34.0 \%$ & $46.2 \%$ \\
\hline Myocardial infarction & $70.2 \%$ & $92.4 \%$ \\
\hline Kidney diseases & & 0.01 \\
\hline Lower limb artherosclerosis & $31.7 \%$ & $28.0 \%$ \\
\hline
\end{tabular}

The following pattern was also observed in the responses to the questions about the causes and consequences of arterial hypertension. Adolescents from the rural-urban area less frequently associated target organ damage with HT. Yet, both groups rarely associated kidney diseases and stroke with hypertension (Table 5).

\section{Discussion}

In our study the rural-urban adolescents dedicated considerably more time both daily and weekly to out-of-school physical activities and concurrently these junior-high school students were significantly more likely to smoke than urban high-school students. Disturbingly, the age of smoking initiation among adolescents in urban-rural area is approximately 2 years earlier in comparison to students dwelling in the bigger cities. Both groups of surveyed teenagers accurately identified unhealthy diet, smoking and excessive alcohol consumption with incident of the commonest cardiovascular consequences. Interestingly, this association is poor with respect to cerebrovascular consequences. Knowledge about risky health behaviors as well as causes and consequences of hypertension is significantly better among urban youngsters, however no significant difference was observed in terms of regular pro-healthy behaviors in the studied populations.

\section{Physical activity}

Physical activity is considered one of the crucial elements of a healthy lifestyle. The World Health Organization (WHO) recommends adolescents to engage in physical exercise for at least 60 minutes every day in order to preserve health [11]. The health benefits following that routine are well-established [12-13].

However, recent meta-analysis including 34 countries shows that only $23 \%$ of boys and $15 \%$ of girls meet these WHO criteria [14-15]. This trend is reflected in the Polish population, where only around one in five adolescents declares moderate to vigorous physical activity (at least 60 minutes of exercise for 7 days/ week) [16]. In contrast, both of the groups we studied appear to meet the above criteria. Nonetheless, a distinct discrepancy is observed - both daily and weekly exercise were significantly higher in rural-urban group. The following trend was reflected in HBSC 2014 stu$\mathrm{dy}$, where factors such as place of residence - namely rural-urban area favored physical activity [17]. This trend can be explained by several factors. Greater presence of shopping centers and cinemas in urban areas creates opportunities for passive leisure activities. For instance, in 2016 8-16\% of students from two major Polish cities of Kraków and Katowice declared to visit a shopping center on a daily basis [18]. It is also important to mention, that limited access to sport facilities, such as swimming pools or stadiums, in rural-urban areas did not facilitate participating in sport activities by studied adolescents. Still, many participants reported being active in local parks, playgrounds. Another important issue differentiating both groups may be a way of commuting to school. In rural-urban areas school is often easily accessible on foot or by bike. In contrast, studies show that as many as $40 \%$ of students in urban area are driven to school by their parents and one in five rides public transportation [19].

\section{Smoking}

Tobacco smoking is an important CVD risk factor, responsible for short term consequences such as shortness of breath, higher resting heart rate, biochemical 
blood changes - increased LDL level and higher insulin resistance, which in adulthood evolves to atherosclerosis [20], stroke [21] or myocardial infarction [22].

Over the past decade the positive trend in smoking cessation was observed in both the pediatric [23] and adult populations [24]. However, the prevalence of smoking in adolescents is still high. An American questionnaire-based study assessed that percentage of students who smoke cigarettes in junior-high and in high school is $2.2 \%$ and $8 \%$, respectively $(7.2 \%$ and $20.2 \%$ for any tobacco products) [25]. In the EU the percentage of adolescents (13-17 years of age) who declare active smoking is even higher, with some studies reporting up to $30.9 \%$ of active smokers [26]. A questionnaire-based study, conducted in semi-urban district of Istambul among 11-14 year olds describes the prevalence of smoking at least once in the participant's lifetime at the level of $12 \%$ and the rate of current smoking as 3.6\% [27]. At the same time the HBSC 2014 study in Polish population reports the percentage of students who smoke on daily basis or at least once a week at the level of $9 \%$ in urban and $7.7 \%$ in rural-urban area [17].

Our results do not fully support this data. The number of current smokers among the surveyed adolescents in the rural-urban area is twice as high as corresponding number in urban area. Additionally, adolescents in the rural-urban environment are at higher risk of long term consequences, such as COPD or lung cancer development, as they tend to smoke 3 times more cigarettes a day, than their peers in Tricity, which is coupled with their greater exposure to passive smoking.

We also observed significantly more adolescents in rural-urban group who tried smoking at least once in their life. Studies show that of those individuals who have tried smoking, about one-third become daily smokers [28]. More importantly, tobacco usage is extremely addictive among adolescents [29]. Moreover, early onset of smoking appears to entail social consequences, such as lower educational attainment in life and low socio-economic status [28].

Additionally disturbing is the high number of smokers among the parents of our rural-urban respondents. Students from families with at least one parent smoking, self-report smoking more frequently. More importantly, there are over twice as many rural-urban adolescents, who restrain themselves from smoking and at the same time are exposed to tobacco smoke by their parents as in the urban group. Similar situation was reported by Kaleta et al. with almost $40 \%$ of Polish adolescents being exposed to involuntary smoking at home [30]. At the same time it was established that parental tobacco usage poses as a risk factor for adolescents smoking initiation [31].
Adolescents in rural-urban area report being less frequently informed by their doctor about negative consequences of smoking. In turn we observe early smoking initiation, higher percentage of first ever smokers, longer smoking history despite being 2 years younger than their urban peers. Sadly, in both groups less than half of studied population identified tobacco use as stroke risk factor.

What should also be mentioned is that approximately two in three rural-urban and urban adolescents alike, drank alcohol at least once in their life. Our results stand in opposition to several studies which suggest that alcohol drinking habit has greater frequency in rural areas [32-33]. Furthermore, the percentage of rural-urban students, who declared abstinence was higher than in the urban area. It is important to note that our urban respondents were on average 2 years older than their rural-urban peers. Nonetheless, one should be aware that early initiation in alcohol use is connected with greater use in adulthood.

\section{Dietary habits}

The WHO recommendations state that prevailing good health is supported by $400 \mathrm{~g}$ ( 5 portions) of fruit and vegetables per day. Several studies support the beneficial role of such diet in decreasing the risk of CVD [34], diabetes [35], stroke [36] and cancer [37]. What appears to be of a great concern is fact that dietary habits formed in childhood tend to be continued later in adulthood. Therefore, only 1 out of 10 of respondents in both studied groups reporting regular fruit and vegetable consumption is unsatisfactory.

\section{Knowledge of CVD risk factors}

Knowledge of CVD risks factors and preventive measures was generally higher among the urban adolescents, who as mentioned earlier were on average 2 years older than their rural-urban peers. With this in mind our study showed that the greater level of knowledge on CVD risk factors did not clearly correlate with a healthier lifestyle. It remains the matter of a debate whether reported differences may have a potential to modify future CVD incidence. Swedish researchers observed that knowledge of CVD risk factors, such as smoking, had no effect on future use [38]. The following tendency is also visible in our study, where greater knowledge level did not clearly correlate with a healthier lifestyle. The following observation was also demonstrated in CARDIA study, where in the group of young adults knowledge on risk factors itself did not predict a 10-year change in CVD risk factors intensity (marginal impact on reducing obesity rates) [39]. 
Despite the lack of direct evidence of the influence of risk factors awareness among adolescents, on the development of CVD in adulthood, it should be mentioned that it may potentially lower the probability of CVD in long term.

\section{Conclusion}

In general, rural-urban and urban students have sufficient theoretical background on the role of heal- thy lifestyle to effectively prevent cardiac diseases in adulthood. However, the surveyed teenagers are rarely aware of the link between hypertension, and smoking to cerebrovascular consequences such as stroke. The latter may have a substantial impact on smoking patterns, particularly among the rural-urban students, which is an area for intensifying the education and introduction of all other preventive measures. Although, the level of knowledge on CVD risk factors is higher among teenage students from urban areas, this does not necessarily translate to a healthier lifestyle.

Attachment 1. Survey questionnaire adapted from Ostrówka D et al. [9]
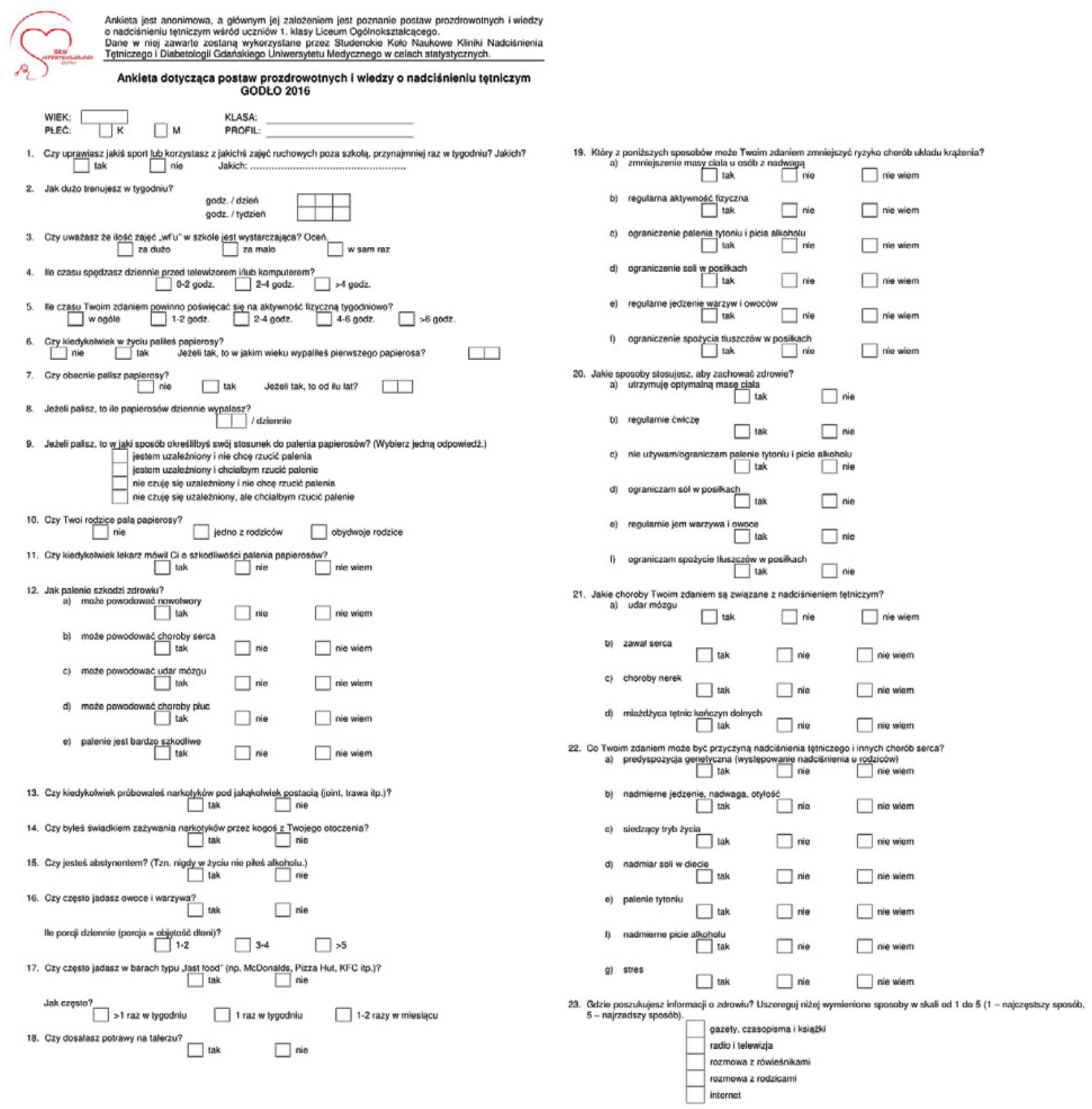

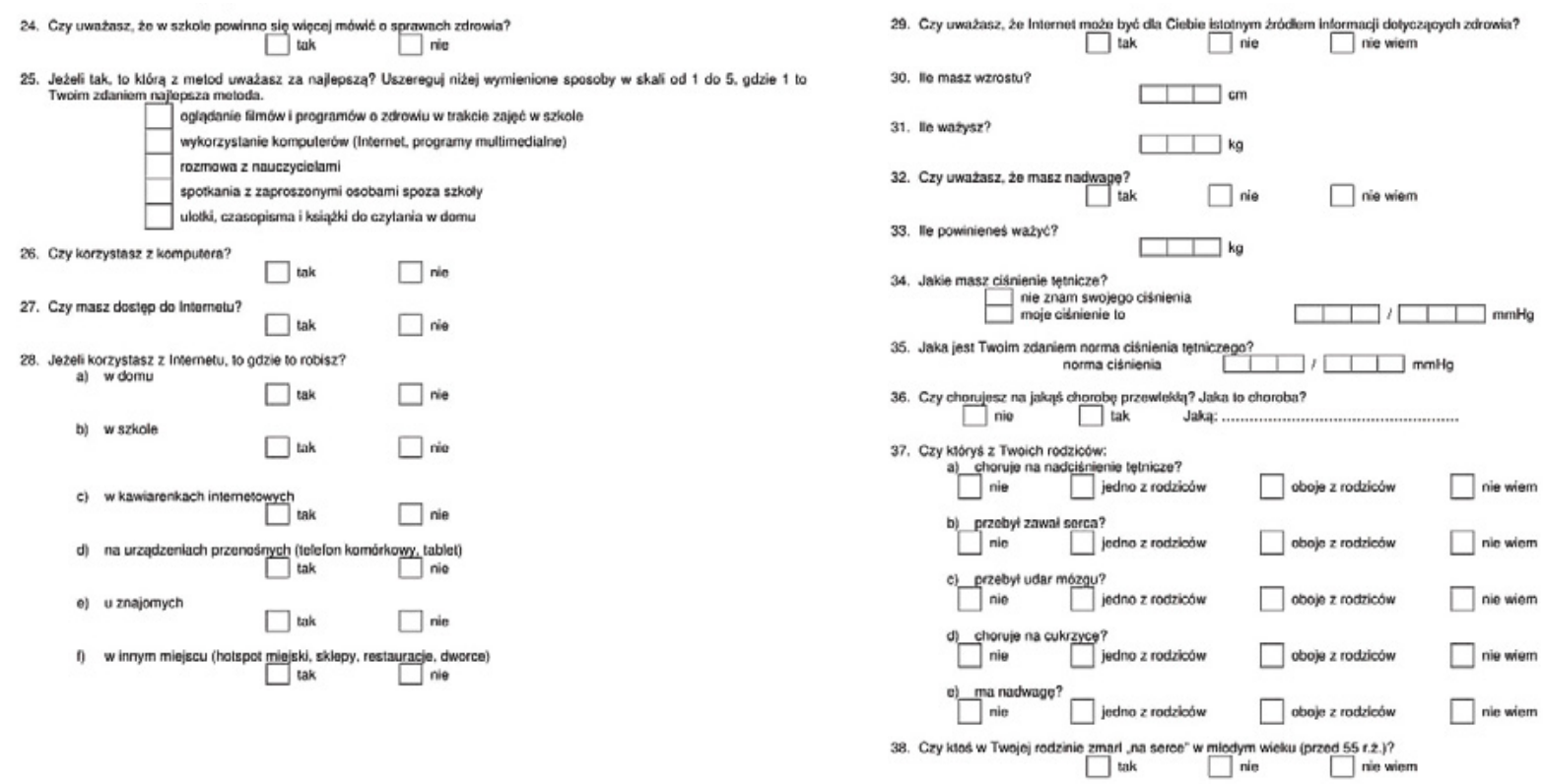

References

1. Lurbe E, Cifkova R, Cruickshank JK, Dillon MJ, Ferreira I, Invitti C, et al. Management of high blood pressure in children and adolescents: recommendations of the European Society of Hypertension. J Hypertens [Internet]. 2009 Sep;27(9):171942. Available from: https://insights.ovid.com/crossref?an=00004872-200909000-00001

2. Litwin M, Michałkiewicz J, Gackowska L. Primary Hypertension in Children and Adolescents is an Immuno-Metabolic Disease with Hemodynamic Consequences. Curr Hypertens Rep [Internet]. 2013 Aug 5;15(4):331-9. Available from: https:// doi.org/10.1007/s11906-013-0360-5

3. Tenfold increase in childhood and adolescent obesity in four decades: new study by Imperial College London and WHO [Internet]. WHO. 2017 [cited 2019 Dec 30]. Available from: https://www.who.int/news-room/detail/11-10-2017-tenfold-increase-in-childhood-and-adolescent-obesity-in-four-decades-new-study-by-imperial-college-london-and-who

4. Wolnicka K, Taraszewska A, Jaczewska-Schuetz J. Prevalence of overweight, obesity and underweight among 3rd grade students of primary schools taking into account regional differences. Endocrin Obes Met Disor [Internet]. 2012;8:80-8. Available from: https://journals.viamedica.pl/eoizpm/article/view/25934

5. Olshansky SJ, Passaro DJ, Hershow RC, Layden J, Carnes BA, Brody J, et al. A potential decline in life expectancy in the United States in the 21st century. N Engl J Med [Internet]. 2005 Mar 17;352(11):1138-45. Available from: http://www. nejm.org/doi/abs/10.1056/NEJMsr043743

6. Preston SH, Vierboom YC, Stokes A. The role of obesity in exceptionally slow US mortality improvement. Proc Natl Acad Sci [Internet]. 2018 Jan 30;115(5):957-61. Available from: http://www.pnas.org/lookup/doi/10.1073/pnas.1716802115

7. Wills TA, Sargent JD, Knight R, Pagano I, Gibbons FX. E-cigarette use and willingness to smoke: a sample of adolescent non-smokers. Tob Control [Internet]. 2016 Apr;25(e1):e52-9. Available from: http://dx.doi.org/10.1136/tobaccocontrol-2015-052349

8. Conner M, Grogan S, Simms-Ellis R, Flett K, Sykes-Muskett B, Cowap L, et al. Do electronic cigarettes increase cigarette smoking in UK adolescents? Evidence from a 12-month prospective study. Tob Control [Internet]. 2018;27(4):365-72. Available from: http://dx.doi.org/10.1136/tobaccocontrol-2016-053539

9. Ostrówka $D$, Jancewicz $M$, Komand $A$, Nowak $M$, Łubiarz $M$, Furtak $M$, et al. Awareness of the role of cardiovascular risk factors and their prevention from the perspective of Tricity adolescents. Arter Hypertens [Internet]. $2017 \mathrm{Mar}$ 30;21(1):51-9. Available from: https://journals.viamedica.pl/arterial hypertension/article/view/51000

10. Siatki centylowe dzieci i młodzieży w wieku 3-18 lat [Internet]. Instytut 'Pomnik Centrum Zdrowia Dziecka'. 2019 [cited 2019 Dec 30]. Available from: http://www.czd.pl/index.php?option=com content\&view=article\&id=1717\&ltemid=538

11. Physical activity and young people [Internet]. WHO. [cited 2019 Dec 30]. Available from: https://www.who.int/dietphysicalactivity/factsheet young people/en/ 
12. Farpour-Lambert NJ, Martin XE, Bucher Della Torre S, von Haller L, Ells LJ, Herrmann FR, et al. Effectiveness of individual and group programmes to treat obesity and reduce cardiovascular disease risk factors in pre-pubertal children. Clin Obes [Internet]. 2019 Dec 1;9(6):e12335. Available from: https://doi.org/10.1111/cob.12335

13. Cuenca-García M, Ortega FB, Ruiz JR, González-Gross M, Labayen I, Jago R, et al. Combined influence of healthy diet and active lifestyle on cardiovascular disease risk factors in adolescents. Scand J Med Sci Sports [Internet]. 2014 Jun 1;24(3):553-62. Available from: https://doi.org/10.1111/sms.12022

14. Guthold R, Cowan MJ, Autenrieth CS, Kann L, Riley LM. Physical activity and sedentary behavior among schoolchildren: a 34-country comparison. J Pediatr [Internet]. 2010;157(1):43-49.e1. Available from: http://dx.doi.org/10.1016/i. ipeds.2010.01.019

15. Belton S, O' Brien W, Meegan S, Woods C, Issartel J. Youth-Physical Activity Towards Health: evidence and background to the development of the Y-PATH physical activity intervention for adolescents. BMC Public Health [Internet]. 2014 Dec 5;14(1):122. Available from: https://doi.org/10.1186/1471-2458-14-122

16. Mazur J, Oblacińska A, Jodkowska M, Małkowska-Szkutnik A, Tabak I, Zawadzka D, et al. Aktywność fizyczna młodzieży szkolnej w wieku 9-17 lat, aktualne wskaźniki, tendencje ich zmian oraz wybrane zewnętrzne i wewnętrzne uwarunkowania. Instytut Matki i Dziecka, projekt realizowany na zlecenie Ministerstwa Sportu i Turystyki, Warszawa. 2013.

17. Oblacińska A. Zdrowie i zachowania zdrowotne młodzieży szkolnej w Polsce na tle wybranych uwarunkowań socjodemograficznych. Wyniki badań HBSC. Warszawa: Instytut Matki i Dziecka. 2015.

18. Sociologist: For many teenagers shopping malls are the modern day yards [Internet]. Science in Poland. 2015 [cited 2019 Dec 30]. Available from: http://scienceinpoland.pap.pl/en/news/news\%2C406860\%2Csociologist-for-many-teenagersshopping-malls-are-the-modern-day-yards.html

19. Polskie dzieci (wciąż) jeżdżą do szkoły samochodami [Internet]. Transport Publiczny. [cited 2019 Dec 30]. Available from: https://www.transport-publiczny.pl/wiadomosci/polskie-dzieci-wciaz-jezdza-do-szkoly-samochodami-59528.html

20. Siasos G, Tsigkou V, Kokkou E, Oikonomou E, Vavuranakis M, Vlachopoulos C, et al. Smoking and atherosclerosis: mechanisms of disease and new therapeutic approaches. Curr Med Chem [Internet]. 2014;21(34):3936-48. Available from: https://www.ingentaconnect.com/content/ben/cmc/2014/00000021/00000034/art00004\#Refs

21. Shah RS, Cole JW. Smoking and stroke: the more you smoke the more you stroke. Expert Rev Cardiovasc Ther [Internet]. $2010 \mathrm{Jul}$ 10;8(7):917-32. Available from: https://doi.org/10.1586/erc.10.56

22. Oliveira A, Barros $H$, Júlia Maciel $M$, Lopes $C$. Tobacco smoking and acute myocardial infarction in young adults: $A$ population-based case-control study. Prev Med (Baltim) [Internet]. 2007 Apr;44(4):311-6. Available from: https://doi. org/10.1016/i.ypmed.2006.12.002

23. Mazur J, Dzielska A, Kowalewska A, Fijałkowska A. Current trends in tobacco smoking among 15 -year-old adolescents in Poland in the background of 30 countries. Przegl Lek [Internet]. 2016;73(10):685-9. Available from: http://www.ncbi. nlm.nih.gov/pubmed/29688683

24. Polakowska M, Kaleta D, Piotrowski W, Topór-Mądry R, Puch-Walczak A, Niklas A, et al. Tobacco smoking in Poland in the years from 2003 to 2014. Multicentre Natl Popul Heal Exam Surv (WOBASZ) Pol Arch Intern Med [Internet]. 2017;127(2):919. Available from: https://pdfs.semanticscholar.org/d404/098b75cee94017fad84b373ae226c8ffb47c.pdf

25. Gentzke AS, Creamer ML, Cullen KA, Ambrose BK, Willis G, Jamal A, et al. Vital signs: tobacco product use among middle and high school students - United States, 2011-2018. MMWR Morb Mortal Wkly Rep [Internet]. 2019;68(6):157-64. Available from: https://www.ncbi.nlm.nih.gov/pmc/articles/PMC5991815/

26. Banzer R, Haring C, Buchheim A, Oehler S, Carli V, Wasserman C, et al. Factors associated with different smoking status in European adolescents: results of the SEYLE study. Eur Child Adolesc Psychiatry [Internet]. 2017 Nov 6;26(11):1319-29. Available from: https://doi.org/10.1007/s00787-017-0980-4

27. Kaya CA, Unalan PC. Factors associated with adolescents' smoking experience and staying tobacco free. Ment Health Fam Med [Internet]. 2010 Sep;7(3):145-53. Available from: http://www.ncbi.nlm.nih.gov/pubmed/22477936

28. Health NCfCDPaHPUOoSa. Social, Environmental, Cognitive, and Genetic Influences on the Use of Tobacco Among Youth. 2012;

29. Zhan W, Dierker LC, Rose JS, Selya A, Mermelstein RJ. The natural course of nicotine dependence symptoms among adolescent smokers. Nicotine Tob Res [Internet]. 2012 Dec 1;14(12):1445-52. Available from: https://academic.oup.com/ ntr/article-lookup/doi/10.1093/ntr/nts031

30. Kaleta D, Polanska K, Wojtysiak P, Szatko F. Involuntary smoking in adolescents, their awareness of its harmfulness, and attitudes towards smoking in the presence of non-smokers. Int J Environ Res Public Health [Internet]. 2017 Sep 21;14(10):1095. Available from: https://doi.org/https://doi.org/10.3390/ijerph14101095 
31. Gilman SE, Rende R, Boergers J, Abrams DB, Buka SL, Clark MA, et al. Parental smoking and adolescent smoking initiation: an intergenerational perspective on tobacco control. Pediatrics [Internet]. 2009 Feb 1;123(2):e274-81. Available from: https://doi.org/10.1542/peds.2008-2251

32. Lambert D, Gale JA, Hartley D. Substance abuse by youth and young adults in rural America. J Rural Heal [Internet]. 2008

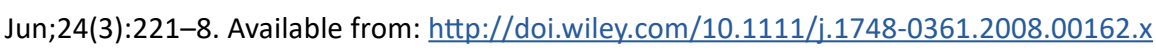

33. Atav S, Spencer GA. Health risk behaviors among adolescents attending rural, suburban, and urban schools: A comparative study. Fam Community Health [Internet]. 2002;25(2):53-64. Available from: https://iournals.Iww.com/familyandcommunityhealth/Fulltext/2002/07000/Health Risk Behaviors among Adolescents Attending.7.aspx

34. Yu D, Zhang X, Gao Y-T, Li H, Yang G, Huang J, et al. Fruit and vegetable intake and risk of CHD: results from prospective cohort studies of Chinese adults in Shanghai. Br J Nutr [Internet]. 2014;111(2):353-62. Available from: https://doi. org/10.1017/S0007114513002328

35. Li M, Fan Y, Zhang X, Hou W, Tang Z. Fruit and vegetable intake and risk of type 2 diabetes mellitus: meta-analysis of prospective cohort studies. BMJ Open [Internet]. 2014;4(11):e005497. Available from: http://dx.doi.org/10.1136/bmjopen-2014-005497

36. Dauchet L, Amouyel P, Dallongeville J. Fruit and vegetable consumption and risk of stroke: a meta-analysis of cohort studies. Neurology [Internet]. 2005;65(8):1193-7. Available from: https://doi.org/10.1212/01.wnl.0000180600.09719.53

37. Boeing H, Bechthold A, Bub A, Ellinger S, Haller D, Kroke A, et al. Critical review: vegetables and fruit in the prevention of chronic diseases. Eur J Nutr [Internet]. 2012;51(6):637-63. Available from: https://doi.org/10.1007/s00394-012-0380-y

38. Povlsen L, Aryal UR, Petzold M, Krettek A. Adolescents' knowledge and opinions about smoking: a qualitative study from the Jhaukhel-Duwakot Health Demographic Surveillance Site, Bhaktapur District, Nepal. Int J Adolesc Med Health [Internet]. 2018;30(1):20150124. Available from: https://doi.org/10.1515/ijamh-2015-0124

39. Lynch EB, Liu K, Kiefe Cl, Greenland P. Cardiovascular disease risk factor knowledge in young adults and 10-year change in risk factors: the Coronary Artery Risk Development in Young Adults (CARDIA) Study. Am J Epidemiol [Internet]. 2006;164(12):1171-9. Available from: https://doi.org/10.1093/aje/kwj334 